\title{
Spatial geometry in Islamic art and architecture
}

\author{
R. Latif \& G. Haider \\ Beaconhouse National University, Pakistan
}

\begin{abstract}
The architects and artists of Muslim history are known for excellence in planar and spatial geometry. We find the application of geometry on tiles and surface patterns and also spatially in architectural construction; the use of geometry is apparent in the arches, domes, and muqarnas, etc. But the use of geometry in the Islamic world is very different from the application of geometry in the western world. The reason for this difference is that grids are not repeated and a linear space is not constructed. A monumental frontal flat space is constructed that prevents the eye from moving into the space unlike the perspective space approached after crossing the structured facade of the Renaissance Church that facilitates the eye to continue inwards. European perspective is geometrically constructed but we don't find any evidence in Islamic work in search of similar devices to represent "real" space.

The purpose of this paper is to identify theoretical aspirations and practical tools in the making of and representation of Islamic architectural space. Certain ideas about perception of architectural space are important to this study; these include implied depth and geometry in pictorial depiction and its implications in architecture. There are several categories in which art can be subdivided including two-dimensional and three-dimensional art like relief and sculpture. In the context of art, to make a clear comparison we will reduce our investigations to two-dimensional art where there is a pictorial depiction of some kind. In traditional cultures two-dimensional art or pictorial imagery often implies a three-dimensional experience depicted on a flat surface. In order to clearly illustrate how space in Islamic architecture is different, we will compare and contrast examples from Islamic Persia and European Renaissance within the period of the 15th-16th century.

Keywords: space, miniature, renaissance, art, architecture, Persia, perspective, shallow space, cross-cultural.
\end{abstract}




\section{Introduction}

Painting in Persian art includes fresco and miniature painting. Frescoes in Pianjikent in the Transoxianan tradition; the 7th-9th century reveal a tradition of wall painting in Persia [1]. The painted scenes are episodes of well-known narratives. It is assumed that the stories were narrated in the rooms where these frescoes were painted serving as visual references while describing the stories. It can be suggested that the miniature was an evolution of the fresco where the relationship between the text, image and the reader is a lot more intimate as only one or two persons can look at an illustration at one time; the viewer himself is the auto-narrator. The Herat Art School was established in the 15th century by the Timurid rulers. It attracted the top artists from Shiraz and Tabriz especially during Sultan Husayn's reign (1469-1506) and Persian painting flourished to its excellence.

Islamic miniatures can be found as illustrations of narrational text, in folios. The narratives illustrated in these are mystical writings, folklore and royal events. Many of these miniatures use architecture as the context where the event takes place. As these miniatures are to be in folios, the relationship to architectural space is very different from the frescoes. The possibility of these miniatures directly being a part of the architectural space is non-existent. There are similarities in how architecture is represented in these miniatures to the actual architecture such as the use of motifs, architectural elements (domes, arches, pistaq, etc).

In the Persian Islamic miniature, perspective as a visual representation of space as seen by the human eyes from a fixed position, characterized by parallel lines seemingly converging to a "vanishing point" is not implied. Instead there is a clear sense of the foreground and background through overlapping and diagonally projecting parallel lines. As all lines are parallel and no lines converge to a single point the illusion of depth is not created and a sense of unfolded or layered, flattened space is introduced.

\section{Renaissance painting and the pursuit of perceptual accuracy}

Art works produced in Europe during the 14th to 17th century are generally classified as Renaissance art. Renaissance art reached its zenith around the early 15 th century to late 16th century. Architecture of the Renaissance implies a rediscovery and recommitment to the Classical Greek-o-Roman manners of thought and discovery, art and architecture. This resulted in a return of classical forms and especially ways of drawing them to communicate perceptually authentic reality. The evolution started in the first half of the 15 th century. Renaissance architecture involves the various experiments conducted from the 15 th century to the 18th century. The initiation is mainly attributed to Filippo Brunelleschi while Alberti gave Renaissance art its theoretical base. The technical, mathematical and geometric model of linear perspective is described by Alberti. The artists and architects of the Renaissance worked together to 
generate the basis for the art work such as statues and murals. In 1435, Alberti explained the rules of perspective; scientifically projecting three-dimensional objects on a two-dimensional paper. Brunelleschi developed a clear and complete system of perspective with the vanishing point. He used mathematically calculated regular diminutions and controlled the viewer's position through distance and direction. Brunelleschi's biographer, Antonio Manetti, described the famous experiment in which Brunelleschi painted two panels (accurate perspectival paintings); one of the baptistery and one for the Piazza della Signora [2].

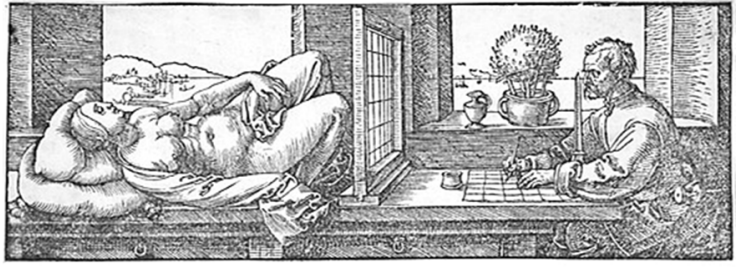

(a)

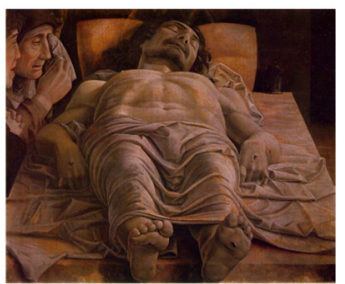

(b)

Figure 1: (a) Draughtsman Making a Perspective Drawing of a Woman, Albrecht Durer, 1525, etching; (b) The Dead Christ, Andrea Mantegna, 1480, tempra on canvas, Milan.

In the painting "The Dead Christ" Mantegna experiments with the laws of the perspective. He uses an unusual vantage point; the viewer is at the feet of Christ. The whole body of Christ is shown foreshortened making the body look wide and swollen. The size of the head does not follow perspective as it should have been much smaller if perspective had been followed.

Rudolf Arnheim [3] writes:

The geometric construct of central perspective approximates the projection that would be received by the eye at one particular station point. Therefore, in order to see the picture "correctly," the viewer would have to assume the corresponding position of standing opposite the vanishing point with his eyes at the level of the horizon. He will also have to be at the proper relative distance.

\section{Persian painting as interpreted narrative}

The seduction of Joseph by Potiphar's wife is an important narrative in the Old Testament and is also part of the Quran. Many visual interpretations of this narrative are present in both Judeo-Christian art as well in Islamic miniatures. This allows us to compare across the two civilizations where the same narrative is depicted. In the Arabic and Persian literary works as well as in commentaries of the Quran the story ranges from the tales of carnal attraction, a timeless tale of love unrequited and divine attachment with miraculous and metaphysical extensions, in love poetry and popular tales [4]. The commentaries suggest that Zulaikha and Yusuf eventually married. This is seen as a recognition of 
Zulaikha's love for Joseph. Mystical poetry also portrays Zulaikha and Joseph as true lovers. The trials are seen as the tests of true love. Jami's version of Zulaikha's love is seen as divine and pure [4]. This position was taken in Jami's poem, Haft Awrang, later illustrated. The western interpretations of the biblical text on Joseph explains the seduction of Joseph as an act of lust and temptation where Joseph is the conservator and not Zulaikha. Another difference is that in the biblical texts Zulaikha is never named and is referred to as Potiphar's wife while the name Zulaikha has been used in the Hebrew and the Islamic traditions and commentaries on the lives of prophets.

Two art works are selected for this comparison both from a similar time period; the 15th-16th century but very different geographical areas and intellectual orientations, one of which is the painting; Joseph and Potiphar's wife by Timtoretto and the other work of art is a miniature painting Joseph and Zuleikha by Bihzad, of Herat produced as part of the Sa'adi poetic collection Bustan. Timtoretto's painting presents Potiphar's wife completely nude pulling off Joseph's cloak. The painting shows the movement of the bodies in detail and the flow of the fabrics. A sense of realness is introduced. The details of the body are worked out to make the whole scene look very real like a photographic image. The folds of the fabric are also worked out showing how light is captured by the fabric. Perfect perspective is not achieved in this painting but there is an attempt to show the distance between the ceiling and the floor (the painting was chosen as the time period was closer to Bihzad's "Joseph and Zuleikha"; later paintings from the 1600 s including Rembrandt's etching of "Joseph and Potiphar's Wife" are more expressive in this regard). The painting expresses the time of the seduction but it does not take into consideration the whole narrative. Miniature paintings have ubiquitous lighting no shadows are cast, this makes the figures and the spaces within the painting as folded out cells of spaces brought together in two dimensional narrational composition. In Bihzad's "Joseph and Zuleikha" architecture is represented using parallel lines and not perspective lines that seem to converge to a point in the space. The miniature painting shows the seven doors of the palace locked by Zuleikha to stop Joseph from escaping as described in the narrative and the labyrinth like positioning of the doors. In Persian literature the opening of these doors is seen as the seven levels of purification that Joseph goes through. The whole scene is unfolded on a flat piece of paper. The depiction of the characters and the space in the painting shows that the artist is not trying to show space as if it has stopped in time but rather as a sequence of unfolding events in time. The attempt to depict reality in represented space through the use of perspective is not apparent in Islamic Persian art.

Western art is made at a scale where it starts to respond to the architectural space either as frescoes on a church wall indicating the continuation of the space from within the architectural space to the painted space or as alter pieces that become the focus of all lines converging in a church inducing the realness of the body of Christ. It is important to also analyze the Islamic Fresco in comparison to the western fresco to conclude a view on the representation or implication of depth in either parts of the world. 


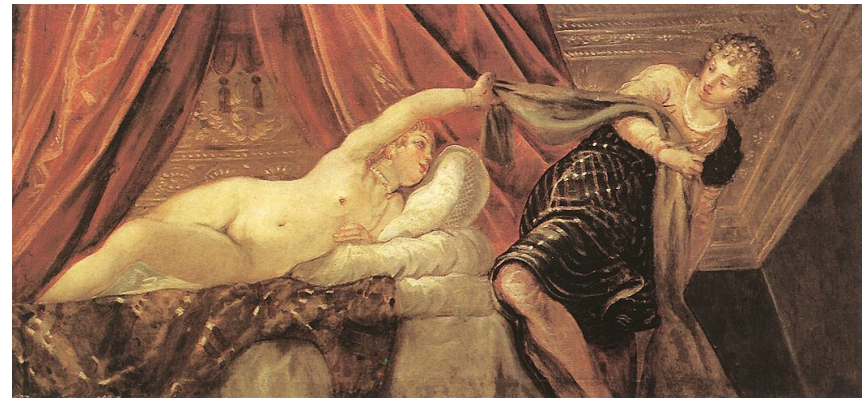

(a)

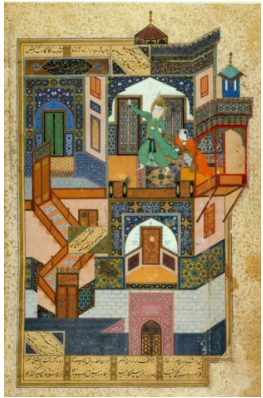

(b)

Figure 2: (a) Joseph and Potiphar's Wife, c. 1555, oil on canvas, $54 \times 117 \mathrm{~cm}$, Timtoretto, Museo del Prado, Madrid; (b) "Joseph and Zuleikha (Potiphar's wife)", 'Seduction of Joseph', Bihzad, Sa'di Bustan, 1488. Royal Egyptian Library, Cairo.

Raphael's School of Athens painting inside the Vatican Palace is an example of the western fresco art. The architectural space depicted in the painting is very much the same as the architectural space within the Vatican. The vaulted roofs, the openings in the roof for lighting, the grid, the columns, the sculptures in the painted space seem to be directly influenced by the architectural space. The painted space maintains the sense of perspective and depth that is exaggerated through the alignment and the order of the architectural elements such as the regular intervals of the columns, roof and floor grids. The painted space is constructed to be viewed from a specific point, if viewed from elsewhere distortions are apparent as the surface onto which the painting is made is flat and not curved. The construction of the space is through the use of geometry and the perspective; all the lines seem to be converging to one point, the convergence of these lines and the visual reduction in the distances between the columns (and

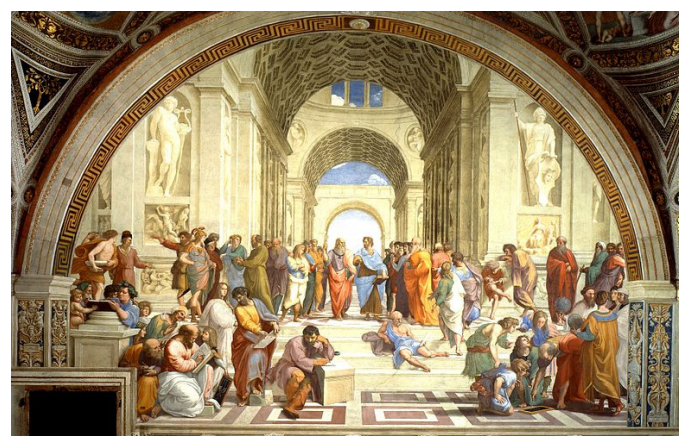

Figure 3: The School of Athens, Fresco, 1509-1510, Apostolic Palace, Vatican City by Raphael. 


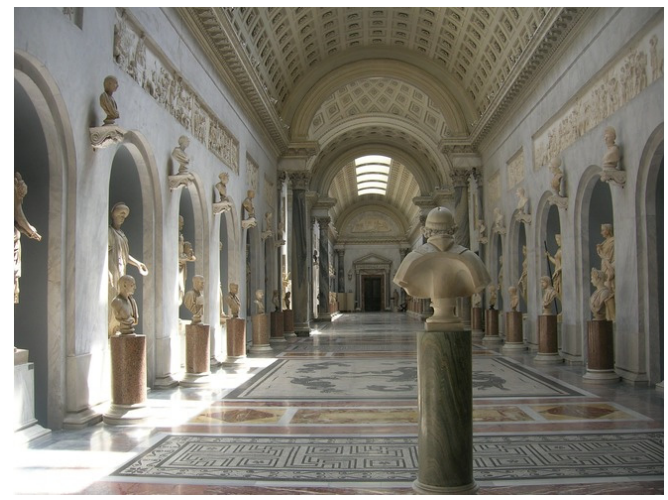

Figure 4: The Vatican Museum.

other gridded elements) due to this convergence is accurately calculated. A clear sense of the foreground and the background is established through the use of the perspective.

The Chehel Satoun is a pavilion palace built by Shah Abbas II in 1647. The pavilion walls are covered with Frescoes, the top and the roof area are covered with floral and geometric pattern, the lower portion of which are paintings very similar in the treatment of planes to Persian miniature paintings. There are 4 frescoes in the Chehel Satoun from the 17th century; Battle of Taher-Abad in 1510, Shah Tahmasp receiving the exiled Mughal Emperor Humayun, Shah Abbas I receiving Vali Nadr Muhammad Khan and the Shah Abbas II receiving Nader Mohammad Khan.

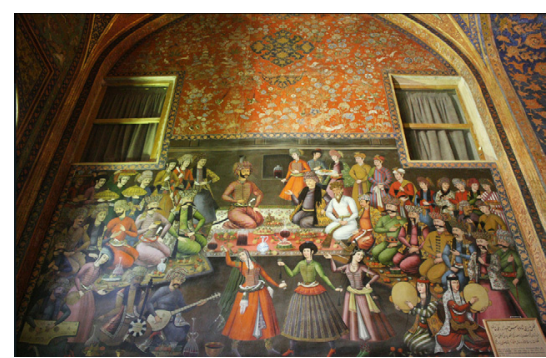

(a)

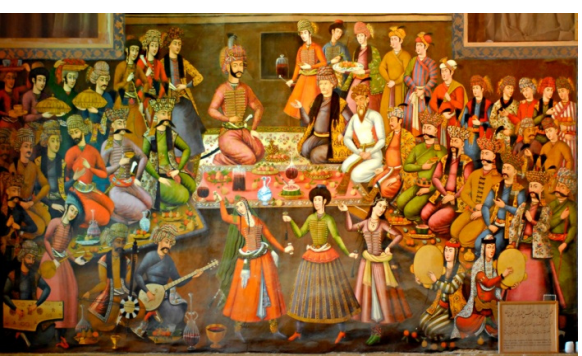

(b)

Figure 5: (a) In perspective: Shah Abbas II receiving Vali Nadr Muhammad Khan; (b) from the front: Shah Abbas II receiving Vali Nadr Muhammad Khan.

The sizes of the figures in these paintings are determined by the stature of the depicted character, the size is not determined by the sequence or closeness to the viewer. The size of the frescoes and all the characters is large as the figures are to be viewed from a distance, the figure of the Shah is exaggerated showing a hierarchy. The planes are distorted, the people seated are shown from a top 
angle rather than the side view used to represent the figures in the front. There is no application of the perspective or any continuation of the built architectural spaces around the fresco. The viewer gazes into a celebratory event which could actually be a set of different events brought into one fresco the main characters of which need to be the host Shah Abbas II and Vali Nadr Muhammad Khan. The fresco might create the effect of a snapshot of a royal reception but it is narration of an intended diplomatic encounter, which in this regard is celebratory represented through the music, dancing, audience and the host but the view is not meant to bring back the exact moment when the event took place. The architecture depicted in the fresco paintings uses the front elevation view or the oblige angled view similar to the depiction in the miniature paintings.

\section{Architecture: a comparison}

Construction and decorative techniques that already existed in Iran and the eastern Islamic world, Byzantine areas of Asia Minor and Syria and Anatolia were adopted by the Seljuqs and appropriated accordingly. The first permanent Seljuq buildings were built in Turkmenistan and Iran. A lot of these buildings have been destroyed due to earthquakes and the Mongol invasions. Funerary monuments, free-standing towers, mosques, and caravanserai are the most common surviving Seljuk buildings.

The architecture of the Timurid period can be categorized mainly in the following four distinct timeframes.

- $\quad$ Timur (1370-1405);

- Shah Rukh and his wife Gawharshad (1405-1447);

- Sultan Husayn Bayqara and his confidant 'Ali Shir Nava'i (1470-1506);

- Timurid rivals in western Iran: the Qaraqoyunlu or Black Sheep (1380 1468) and the Aqqoyunlu or White Sheep (1378-1508).

Babur (1483-1530) a descendant of Timur later formed the Indian Mughal dynasty.

The Renaissance can be divided into the following three phases:

- The Early Renaissance (1400-1500). The early Renaissance style was based on the revival of ancient architectural principles, the use of modular, monolithic grey stone columns and pilasters on white plaster walls. Brunelleschi was an important architect during the period. Alberti introduced the triumphal arch and the temple front to his churches [5].

- The High Renaissance (1490-1527). The high Renaissance style was marked with monumentality even at a small scale mimicking the massive Roman imperial architecture, the buildings also became more decorative. Michelangelo (1475-1564) and Palladio (1508-1580) are two important architects from the sixteenth century. During the Renaissance there were no clear divisions between the disciplines many artists and the architects worked in collaboration or were masters of both domains. 
- Mannerism (1500-1600). The art works during this period represented ideal beauty rather than natural beauty by using exaggerations of the human proportions and the perspective.

In Figure 6, two images of Brunelleschi's Church San Lorenzo in Florence are shown; Figure 7 shows an image of the Miri-Arab madrassah in Bukhara. We can see that the space in the Miri- Arab madrassah is flat/shallow unlike the perspectival space of Brunelleschi's Church.
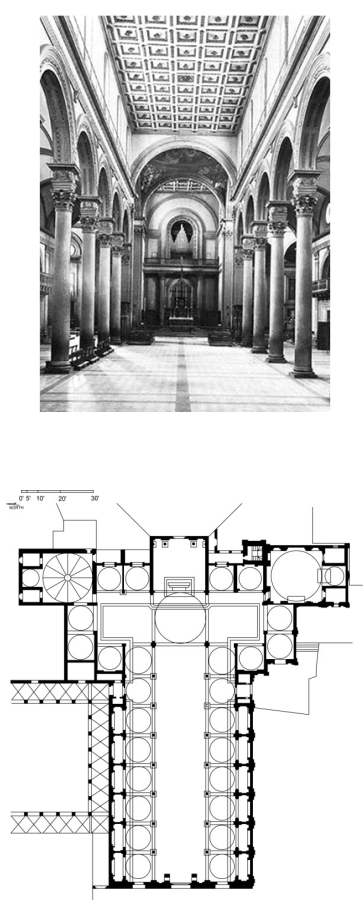

Figure 6: San Lorenzo, Florence, $1422-1470$.
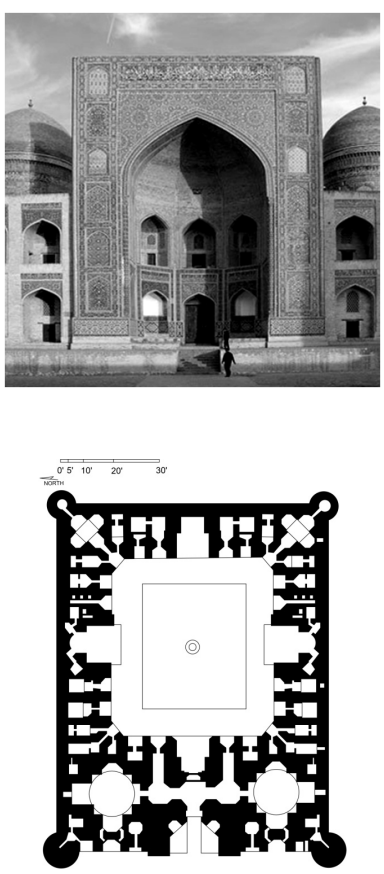

Figure 7: The Miri-Arab madrassah, Bukhara, 1535-1536.

Brunelleschi was able to understand the science behind the perspective by analyzing and experimenting with visual lines and points of perception in the two-dimensional space. In architecture this required the use of identical elements placed at equal distance. Identical elements or those linked by their relationship to each other or whole numbers were used [6]. A square grid was used on the floor/ceiling and the columns followed each other at regular intervals. The square appeared reduced in proportion according to the distance. Wittkower writes about the proportions in San Lorenzo [7]. The visual lines converge at the altar. For every point in the movement towards the nave the proportions diminish 
accordingly while inviting the viewer in and controlling the movement of the viewer. The floor of the nave is made of square marble; corresponding to the lines of the axis and the sizes of the bays. The coffers of the ceiling are metric guides giving spatial co-ordinates to the space of the interior [8].

Moffitt on construction of space in the Renaissance architecture:

Alberti's chief technical problem was to find a rule of construction which relates the distance of the painter (the viewer) from the depicted scene. A particular problem was relating this distance to the receding spatial intervals of a depicted pavement that these intervals will appear to diminish in a regular proportional progression. Brunelleschi must certainly have faced this problem too. The two arcades of the nave of his Florence Church of San Lorenzo, when seen receding to the altar (or toward the door), diminish in such a perfect and definite progression that Professor (Rudolf) Wittkower called this the first true and deliberate example of artistic "proportion in perspective". Of course the architect, working in the three-dimensional space, has only to make the intervals between the columns equal to each other to ensure this visual effect. The viewer may move closer of further away from the altar (nota bene: this is the specific place where the vanishing point emphatically falls) as he likes. As long as the direction of his line of sight, remains the same, that is, as long as it is oriented towards the altar as the centre of vision, he will be struck by this image of proportional diminution [8].

Miri-Arab Madrassah was built during the reign of Ubaydallah Khan, Shaybanid in Bukhara. There are 114 cells for students in the madrassah. The madrassah wall and the resulting depth is geometrically worked out in great detail, the front arch forms a half dome, this dome when touching the vertical sections of the wall makes a smooth transition and several smaller arches are inserted in the front walls which in plan form a half octagon (Fig. 7). The transition from the dome to the vertical walls envelopes space and the vision of the viewer. No attempt is made to allow the viewer's vision to be continued through this space. There is a significant difference between the sizes of the arches in the back walls and the frontal arch, these smaller arches have further smaller opening like arches inside them. These arches again are much smaller than the original arches. The three arches which are significantly important for this comparison are the large frontal arch, the smaller arch with a doorway with in recessed the frontal plane in the same axis as the frontal arch and the arch on top of the doorway arch within the same axis. These arches belong to the same axis with planes moving backwards but the difference in the size is not there because of the distance between one arch and the other or due to the perspective but is a deliberate reduction of size. This does not invite the eye to move in a linear perspective or to induce depth in the space making it look flat. The changes in the axis of the two other walls on the sides of the half hexagonal base also flatten the space as this smooth transition diminishes any empty space that was to form between the front and the back wall. The spatial construction of the 
Miri-Arab madrassah does not take the perspective into consideration but rather diminishes it by the intentional use of non-equal members in the structure and the framing. A different kind of layering is introduced where one layer forms the curtain through which the next layer is introduced.

\section{Conclusions}

We see that in terms of both art and architecture there are similarities within similar regional and cultural boundaries. The space in the Renaissance art and architecture is perspective based. The emphasis on perspective can be seen in the rendering of both art and architecture. Brunelleschi's experiment using the mirror and later renderings of Santo Spirito are based on the accurate visual perception of space. This perspective rendering is very similar to the later use of the camera. The spatial organization and unfolding of space in the Renaissance is rational and straight forward. The understanding of this space can only have one interpretation. The space in Islamic art and architecture is more complex and is also geometrically constructed but is very different from the geometric one point perspective constructions of the Renaissance. Ibn-i- Haitam, an Iraqi scholar, is known to have researched and correctly concluded from scientific proof the functioning of the human eye. He is also credited to having invented the camera obscura. This shows that the Muslim scholars and artists were well aware of how a realistic image could be produced. Islamic architecture is geometrically constructed but is not meant to be viewed from one particular point. It unfolds like the narrative space of a miniature painting with different parts playing different roles in the bigger architectural composition. The spaces have different spatial qualities like the simultaneous events within the miniature painting, one space has to be experienced after the other in real time and space to understand the spatial narrative of the architecture.

It can be concluded that there are similarities when we look at the manner of imagining, designing and constructing space down to even orchestrating how space would be experienced in terms of depth and design elements during a certain time period at a place. The Renaissance is full of examples in art and architecture where there is a conscious and sometimes accentuated use of perspective as both a way of representation (paintings) and choreographed architectural experience (architecture). The accentuated use of the perspective plays an important role in both Renaissance art and architecture. Renaissance art and the architecture is closely related to each other as the scale of the art allows them to become a part of the architectural space. The architectural space is continued into the pictorial narrative space. The spaces within the painted space take clues from the architectural space and how it is visually perceived. The pictorial arts from the Islamic world include miniature paintings and the frescoes, but only very rarely is a fresco painted within a spatial context or with figures. The representation of the architectural spaces is such that the depth is shown by parallel lines/orthogonal lines and not converging lines (perspective). 


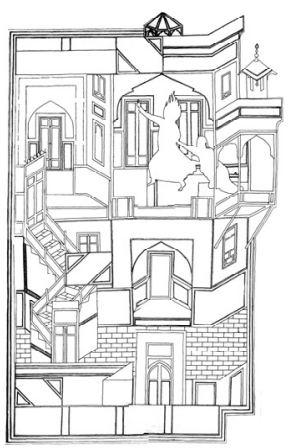

(a)

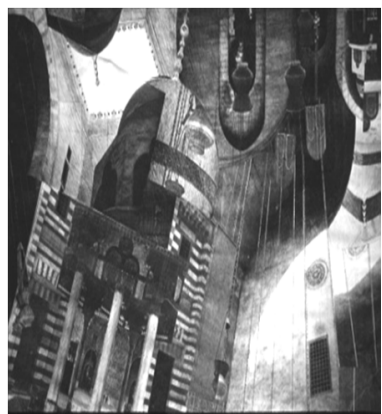

(b)

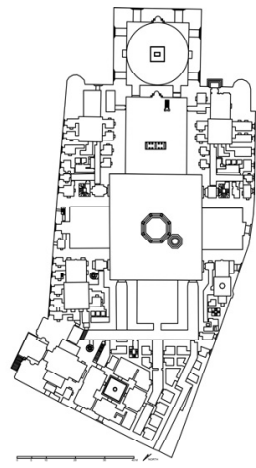

(c)

Figure 8: (a) Line drawing of "Joseph and Zuleikha (Potiphar's wife)", Bihzad, Sa'di Bustan, 1488. Royal Egyptian Library, Cairo; (b) central courtyard's spatial experience painting, Rosita Niknafs, Sultan Hassan Mosque, Cairo; (c) plan of Sultan Hassan Mosque, Cairo, 1356 to 1363.

There are fewer studies on the visual space formation in Islamic civilization. Research has been done on the use of geometry in Islamic art and architecture. The understanding of depth in Islamic art is different from that of the Renaissance. Depth is depicted in Islamic art through orthogonal projections where the lines are parallel to each other, unlike the converging lines of the perspective. In architecture it is translated by avoiding the emergence of a visual line converging to a single point. The problem of depiction of space on a twodimensional surface is a complex problem. The functioning of the human eye is only one part of the answer. The human experience is not just a purely visual experience. The connection between space, time, afterimage and longer term memory makes the experience of architecture into a much more complex experience than what was thought during the Renaissance. The architectural experiences unfold like narratives and the sequence of events change the meaning of the architectural experience.

\section{References}

[1] Canby, S.R.C., Persian Painting, British Museum Press: London, p. 9, 1993.

[2] Woods, K.W., Making Renaissance Art, Yale University Press, pp. 65-67, 2007.

[3] Arnheim, R.A., Art and Visual Perception: A Psychology of the creative mind, University of California Press, p. 287, 1997.

[4] Merguerian, G.K.M., Najmabadi, A. N., Zulaykha and Yusuf: Whose "Best Story"?, International Journal of Middle East Studies, Cambridge University Press, Vol. 29, No. 4 pp. 487-488, Nov. 1997. 
84 Islamic Heritage Architecture and Art

[5] Fletcher, B.F., A History of Architecture, 12th edition, CBS publication: New Delhi, p. 841, 1996.

[6] Leonardo. B.L., The Architecture of the Renaissance, Routledge, Vol. I, p. 52, 2002.

[7] Wittower, R.W., "Brunelleschi and Proportion of Perspective" Journal of the Warburg and Courtauld Institutes, The Warburg Institute, Vol. 16. No. 3/4, pp. 28-289, 1953.

[8] Moffitt, J.F.M., Painterly perspective and piety: religious uses of the vanishing point, from the 15th to the 18th century, McFarland: North Carolina, pp. 24-25, 2008. 